\title{
The Effect of Agitation Parameter on Hardness and Thickness of Decorative Nickel-Chrome Coating on A36 Steel using Electroplating Process
}

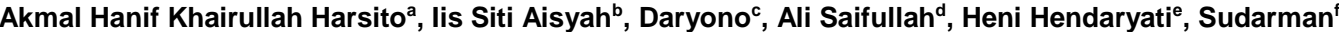 \\ $a, b, c, d, e, f$ Mechanical Engineering, Engineering Faculty, University of Muhammadiyah Malang \\ Raya Tlogomas No.246, Malang, East Java, Indonesia (0341) 464318-319 \\ e-mail: akmalhanif02@gmail.com, siti@umm.ac.id, daryono@umm.ac.id
}

\begin{abstract}
Electroplating is a process of settling substances (metal ions) on the electrodes (cathodes) by means of electrolysis. The occurrence of a precipitate in this process is due to the presence of electrically charged ions moving from an electrode through the electrolyte, the result of the electrolyte will seal on another electrode (cathode). During the process of deposition/deposit takes place a chemical reaction occurs at the electrode and electrolyte both reduction in a certain direction permanently, therefore it requires direct current and a constant voltage. Metal coatings commonly used are copper, nickel, chromium and others. Electroplating is basically to coat the metal to make it look more attractive and protected from corrosion, and can increase the product's resistance to friction. The purpose of this study was to determine the effect of stirrer rpm variations on the thickness and thickness of the A36 steel layer in the decorative nickel-chrome electroplating process. 4 specimens in this study were $30 \times 30 \times 2(\mathrm{~mm})$. Nickel and chromium coatings have variations in the speed of 72, 102, 132 and 162 (rpm) with a time immersion of 22 minutes and with a temperature of $55-60^{\circ} \mathrm{C}$. The results of this electroplating process were tested by Vickers hardness test and observation of microstructure results. The results showed that the faster the rpm, the more hardness was obtained which increased and the thickness of the layer increased. The highest hardness and thickness values are found at a rotational speed of $132 \mathrm{rpm}$. With a hardness value of $77.5 \mathrm{VHN}$ and a thickness value of $4.55 \mu \mathrm{m}$ (Nickel) and $13.76 \mu \mathrm{m}$ (Chrome).
\end{abstract}

Keywords: Electroplating, Nickel, Chrome, rpm Stirrer, A36

\section{INTRODUCTION}

We find almost every tool used by humans is made of metal, namely various jewelry, furniture, various crafts, motorcycle components, cars, and others. Some of the metals used are steel. Steel is divided into two parts, namely high carbon steel and low carbon steel. One of the low carbon steels is A36 steel. Weaknesses of this steel besides being easily corroded are also gray, unattractive, to prevent corrosion as well as to enhance the appearance, plating/coating is carried out.

The main function of the metal coating is to improve the appearance (decorative), also improve the smoothness or surface shape and tolerance of base metals, and also can increase product resistance to friction (abrasion)[1]. In decorative applications, the solution used mostly nickel-plated is often applied in combination with chrome [2]. Electroplating or commonly called chrome serves to coat the metal to make it look more attractive and protected from corrosion. Until now, coating with electroplating has become a trend both in general use and in special uses such as medical equipment. Electroplating coating has a higher hygiene compared to oil paint or sprays paint, this has become one of the references regarding medical circles who use metals with a chrome coating.

Niko Rensen's research states that with the presence of several factors that affect the coating such as the thickness of the coating, the morphology of the coating, the type of material used, time, temperature, and the displacement of the atom itself. Therefore it is 
necessary to use tools that affect the movement of atoms, one of which is with the help of magnetic stirrers [3]. By using a magnetic stirrer using magnetic field rotation to rotate the stir bar, the coating process occurs faster so that the thickness of the coating on the specimen is harder compared to without a magnetic stirrer. Chrome is the finish for the nickel decorative-protective plating system. The color is bluish-white and brilliant, resists tarnish (stain), resists corrosion, resists wear and scratches, and better protects the substrate [4].

Then research [5] revealed that the influence of surface roughness and stirring speed on the characteristics of the Ni-P non-metal layer. The experimental parameters varied, namely surface hardness of $0.044 \mu \mathrm{m}, 0.056 \mu \mathrm{m}, 0.101 \mu \mathrm{m}$, and $0.164 \mu \mathrm{m}$ and stirring speed of $4.9 \mathrm{rpm}, 11.3 \mathrm{rpm}$, and $21.3 \mathrm{rpm}$. The results of the study showed that the coarser surface of the substrate and the faster the stirring the larger the particle size of the formed layer, but not uniformly coated the entire surface of the substrate. The rougher the surface is and the faster the stirring is, the thicker the layer is formed, which is indicated by the payment of the electron microscope (SEM). From this research, research about the effect of RPM stirrer variations on the hardness and yield of A36 steel microstructure in the decorative nickel-chrome electroplating process. Since many application of electroplating products depend on the surface characteristic such as corrosion resistance and wear then it is need to do some experiment to investigate it especially on the hardness and thickness of electroplating. Also, the formation of compound of electroplating involves very complex mechanism so that make a change in one parameters will have influences on the product.

\section{Methods}

In this research, a decorative nickel-chrome electroplating process will be carried out. with a dipping time of 22 minutes and the anodes used are pure nickel and lead. The test that will be carried out in this research is the vickers hardness test which uses a diamond pyramid indenter which is a square shape [6] and a thickness test to find out how thick the layer is attached to the specimen. This research took place on 22 June 2020 to 24 June 2020. The research process can be seen in the flowchart below.

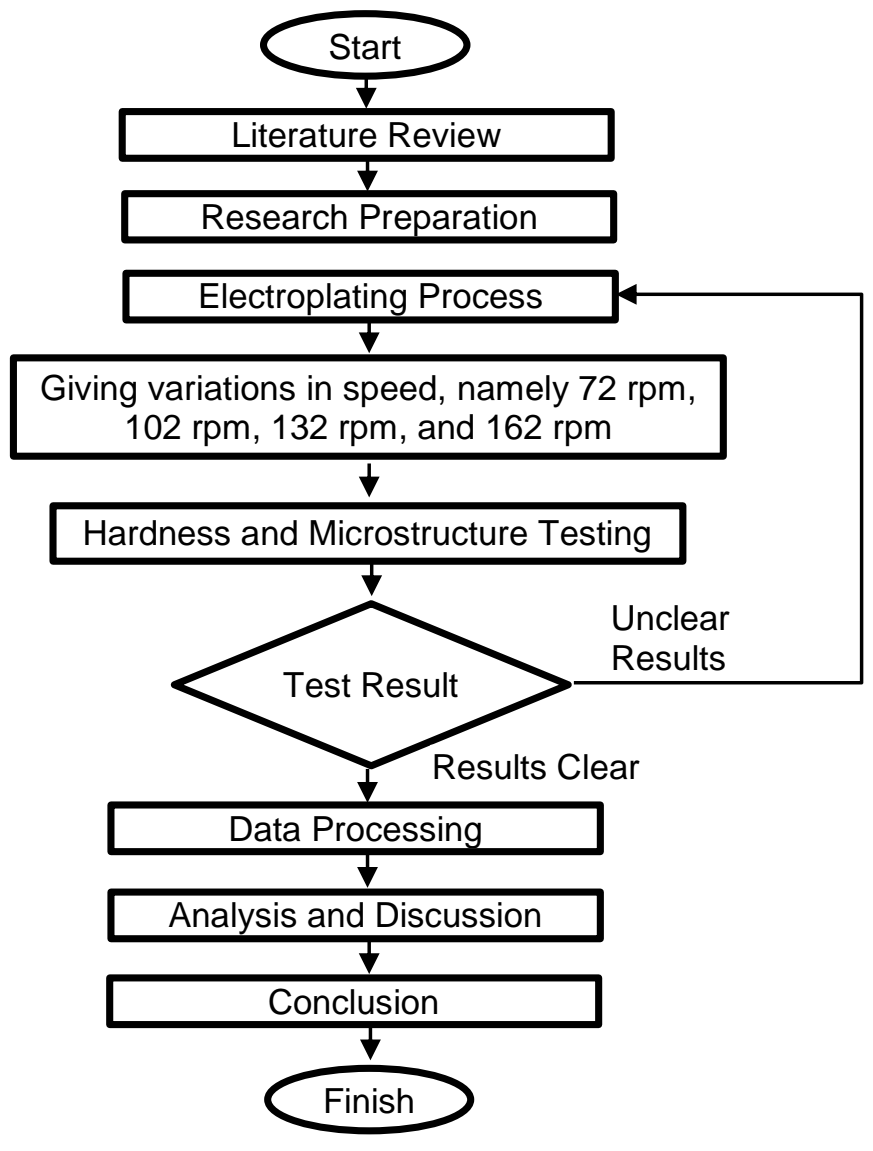

Figure 1. Procedure and Methods 
JEMMME (Journal of Energy, Mechanical, Material, and Manufacturing Engineering) Vol.5, No. 2, November 2020

\section{ResUlt ANd Discussion}

3.1 Hardness test results and thickness results of the chrome-nickel electroplating process

For the results of hardness using Vickers hardness test equipment and for thickness using applications that are connected to the microstructure test equipment.

a. Hardness test result

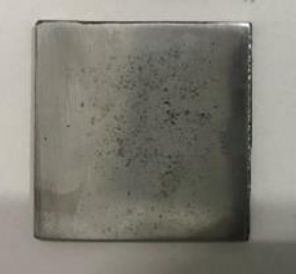

(a) Without Coating

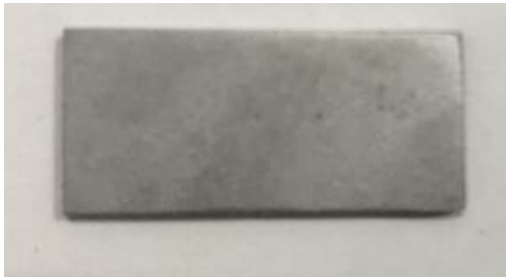

(b) $72 \mathrm{rpm}$

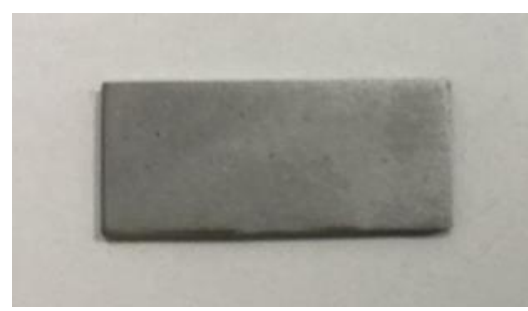

(c) $102 \mathrm{rpm}$

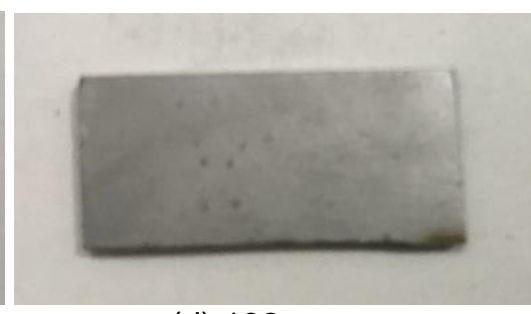

(d) $132 \mathrm{rpm}$

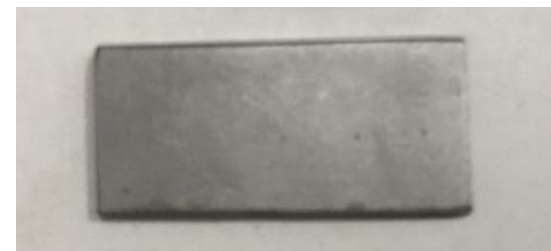

(e) $162 \mathrm{rpm}$

Figure 2 Hardness Test Result

\section{b. Thickness coating result}

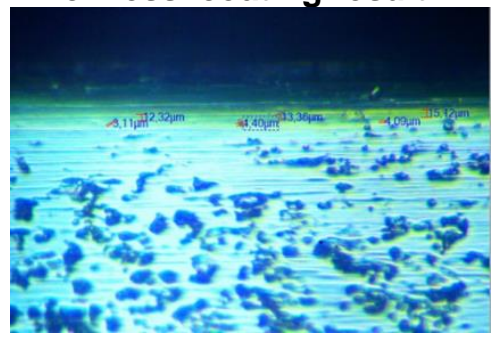

(a) $72 \mathrm{rpm}$

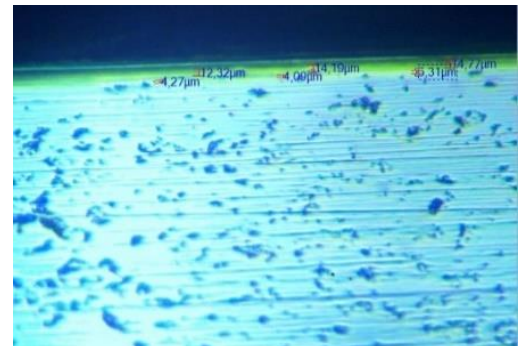

(c) $132 \mathrm{rpm}$

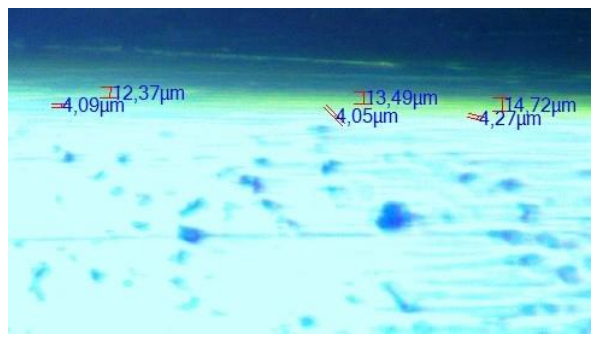

(b) $102 \mathrm{rpm}$

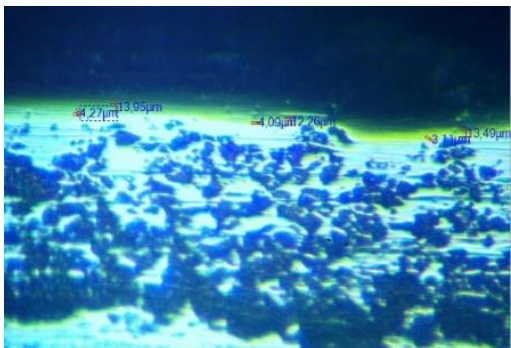

(d) $162 \mathrm{rpm}$

Figure 3 Thickness Coating Result 


\subsection{Data Analysis and Discussion of Electroplating Nickel-Chrome Decorative 3.2.1 Data Analysis and Discussion of Hardness Test Electroplating Nickel-Chrome Decorative \\ a. Without Coating}

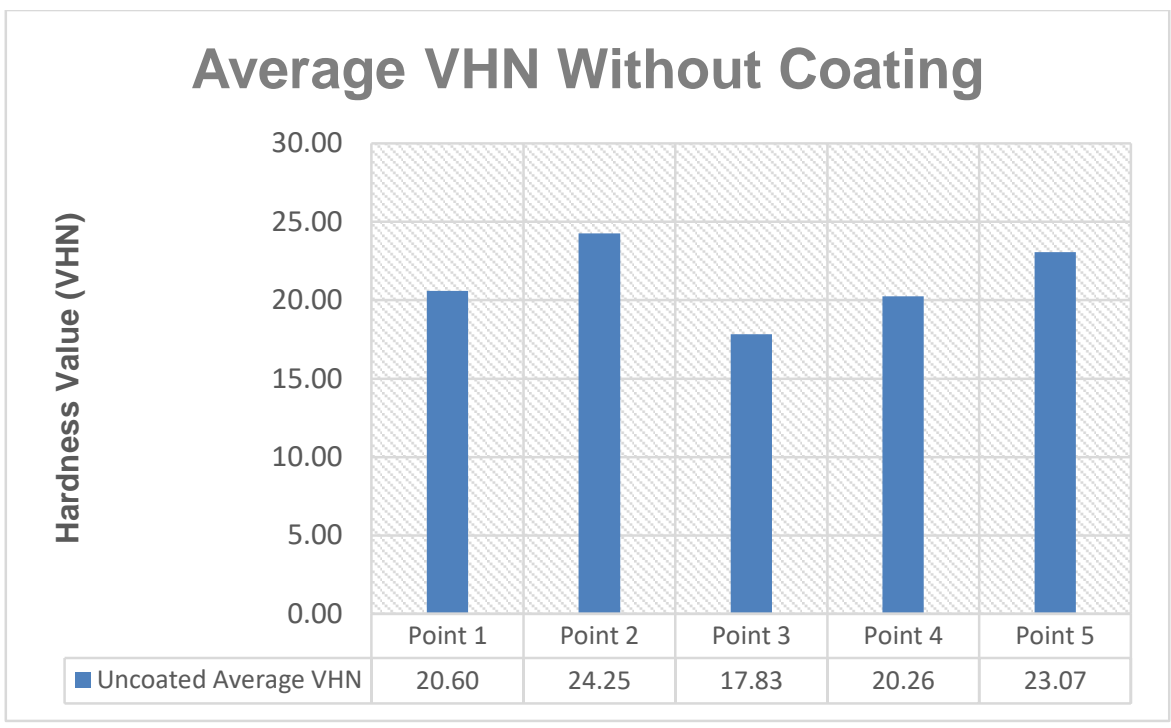

Graphic 1. Hardness Value Without Coating

Based on the graphic 1, it can be analyzed that at point 1 the hardness value is 20.60 $\mathrm{VHN}$, point 2 the hardness value is $24.25 \mathrm{VHN}$, point 3 is the hardness value of $17.83 \mathrm{VHN}$, point 4 is the hardness value of $20.26 \mathrm{VHN}$, and point 5 is the hardness value of 23,07 VHN. Visually seen a fluctuating value in the Vickers hardness test results. The lowest value obtained at point 3 and the highest value obtained at point 2 .

\section{b. Variation Speed of $72 \mathrm{rpm}$}

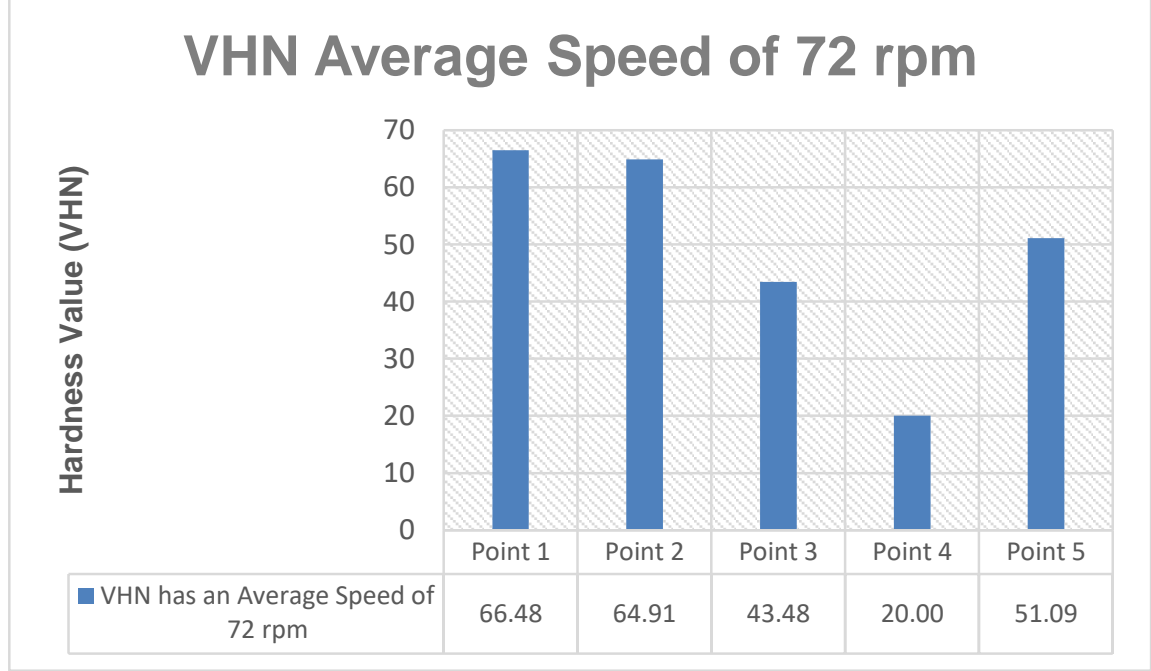

Graphic 2. Hardness Value Average Speed of 72 rpm

Based on the graphic 2, it can be analyzed that at point 1 the value of violence is 66.48 $\mathrm{VHN}$, point 2 the value of violence is $64.91 \mathrm{VHN}$, point 3 the value of violence is 43.48 $\mathrm{VHN}$, point 4 the value of violence is $20 \mathrm{VHN}$, and point 5 the value of violence is 51.09 VHN. Visually seen a fluctuating value in the Vickers hardness test results. The lowest value obtained at point 4 and the highest value obtained at point 1 . 


\section{c. Variation Speed of $102 \mathrm{rpm}$}

\section{VHN Average Speed of 102 rpm}

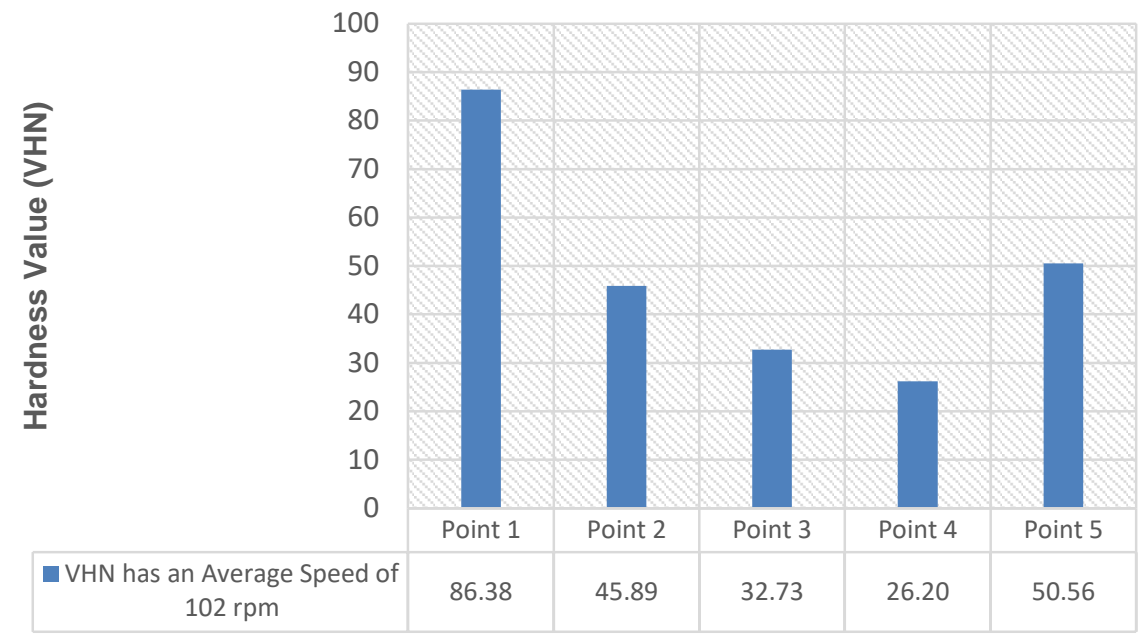

Graphic 3. Hardness Value Average Speed of 102 rpm

Based on the graphic 3 , it can be analyzed that at point 1 the value of violence is 86.38 VHN, point 2 the value of violence is $45.89 \mathrm{VHN}$, point 3 the value of violence is $32.73 \mathrm{VHN}$, point 4 the value of violence is $26.20 \mathrm{VHN}$, and point 5 the value of violence is $50,56 \mathrm{VHN}$. Visually seen a decrease in value in the Vickers hardness test results. The lowest value obtained at point 4 and the highest value obtained at point 1 .

\section{d. Variation Speed of $132 \mathrm{rpm}$}

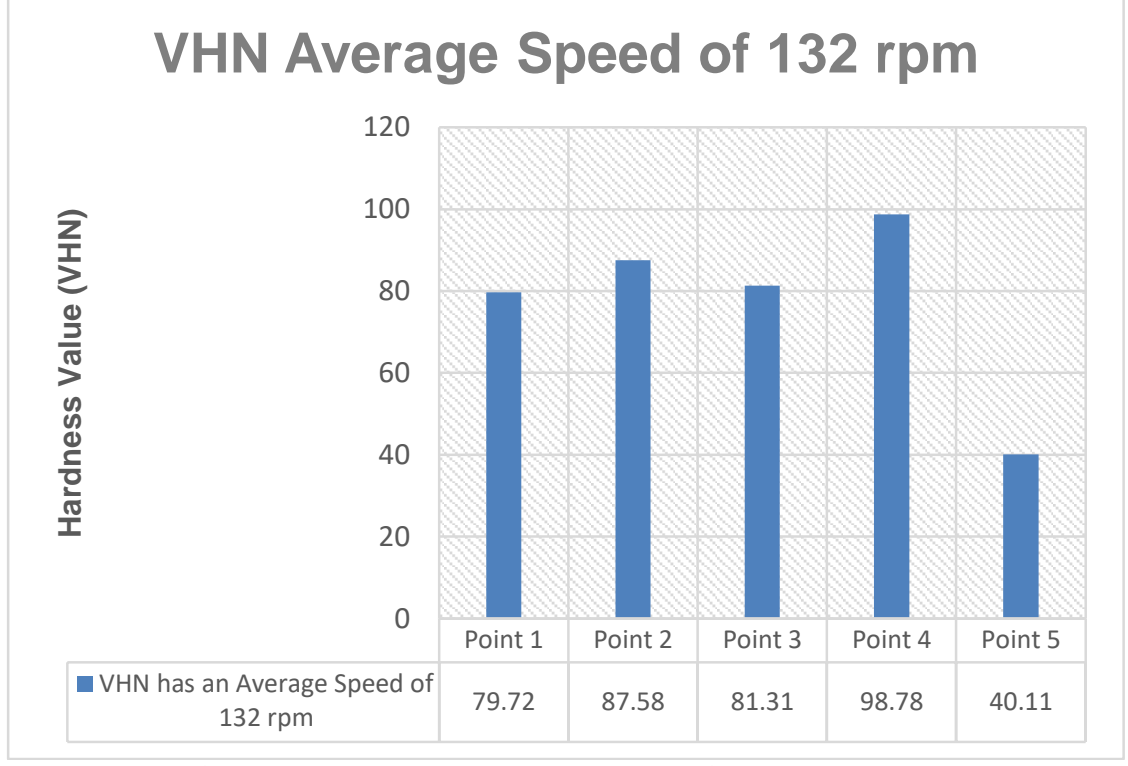

Graphic 4. Hardness Value Average Speed of 132 rpm

Based on the graphic 4, it can be analyzed that at point 1 the value of violence is 79.72 $\mathrm{VHN}$, point 2 the value of violence is $87.58 \mathrm{VHN}$, point 3 the value of violence is 81.31 $\mathrm{VHN}$, point 4 the value of violence is $98.78 \mathrm{VHN}$, and point 5 is the value of violence 40.11 VHN. Visually seen a fluctuating value in the Vickers hardness test results. The lowest value obtained at point 5 and the highest value obtained at point 4 . 
e. Variation Speed of $162 \mathrm{rpm}$

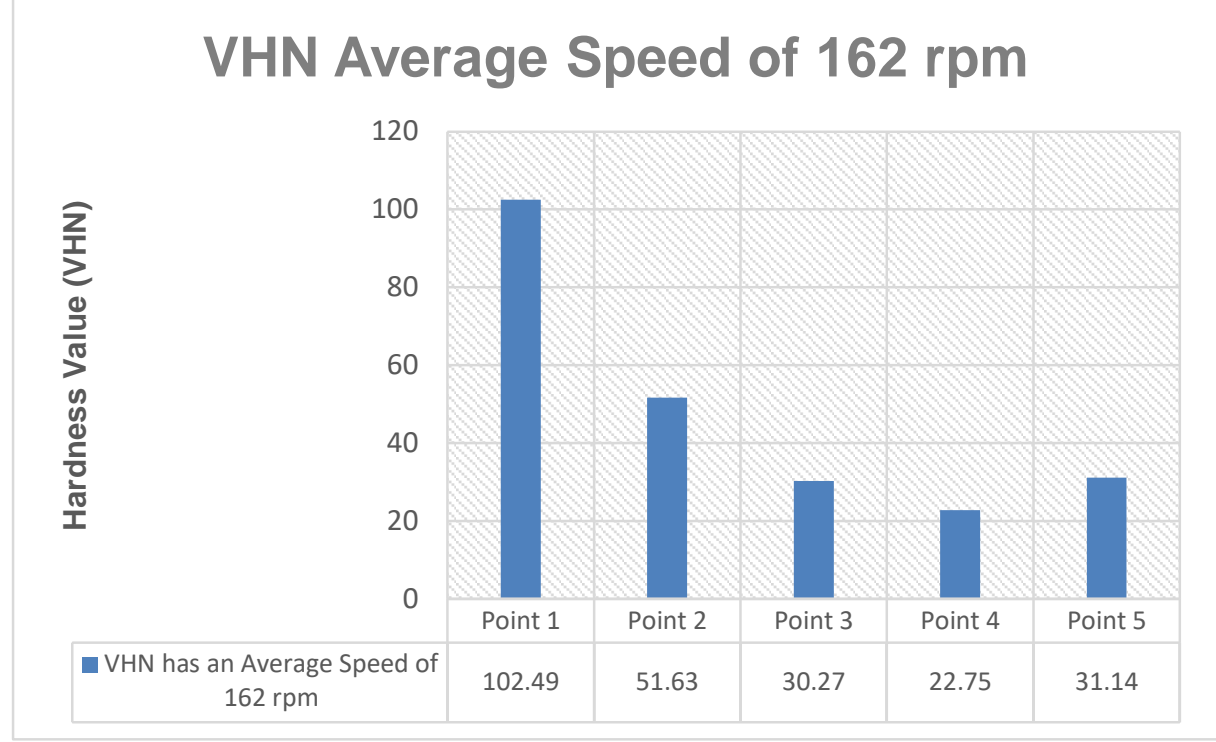

Graphic 5. Hardness Value Average Speed of 162 rpm

Based on the graphic 5, above it can be analyzed that at point 1 the value of violence is $102.49 \mathrm{VHN}$, point 2 the value of violence is $51.63 \mathrm{VHN}$, point 3 the value of violence is $30.27 \mathrm{VHN}$, point 4 is the value of hardness $22.75 \mathrm{VHN}$, and point 5 the value of violence is $31,14 \mathrm{VHN}$. Visually seen a decrease in value in the Vickers hardness test results. The lowest value obtained at point 4 and the highest value obtained at point 1 .

\section{f. Vickers Total Hardness Test Results}

\section{Total Vickers Hardness Test Results}

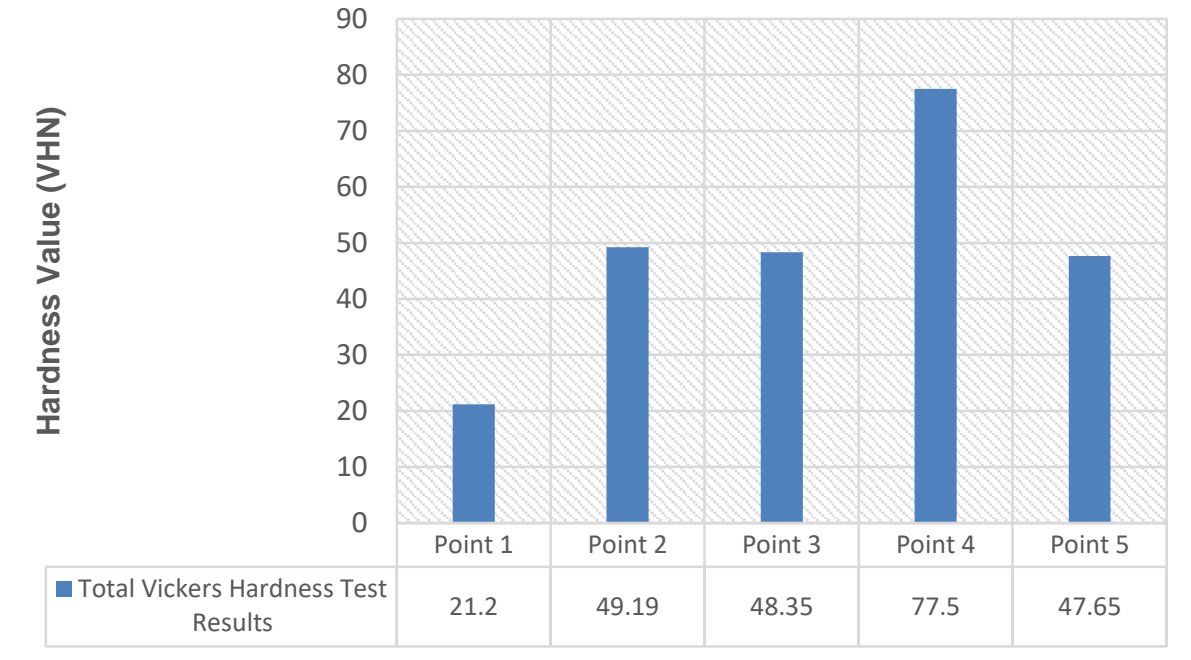

Graphic 6. Vickers Total Hardness Test Result

Based on the graphic 6 , of the total Vickers hardness test results above, it can be analyzed that in specimens without layers the average hardness value is $21.2 \mathrm{VHN}$, at a speed variation of $72 \mathrm{rpm}$ the average hardness value is $49.19 \mathrm{VHN}$, at a speed variation of $102 \mathrm{rpm}$ the average hardness value $48.35 \mathrm{VHN}$, at a variety of speed 132 rpm the average hardness value is $77.5 \mathrm{VHN}$, and at a speed variation of $162 \mathrm{rpm}$ the average hardness value is $47.65 \mathrm{VHN}$. Visually seen a decrease in value in the Vickers hardness test results. The lowest value is obtained in the specimen without layers and the highest value is obtained at a variety of speed $132 \mathrm{rpm}$. The rise and 
fall of the hardness value are caused by the existence of rotation, according to the existence of previous research which states that the decrease in the value of hardness is due to the increasing speed of stirring, the higher the likelihood of defects [7].

\subsubsection{Data Analysis and Discussion of Thickness Coating Electroplating Nickel- Chrome Decorative}

a. Variation Speed of $72 \mathrm{rpm}$

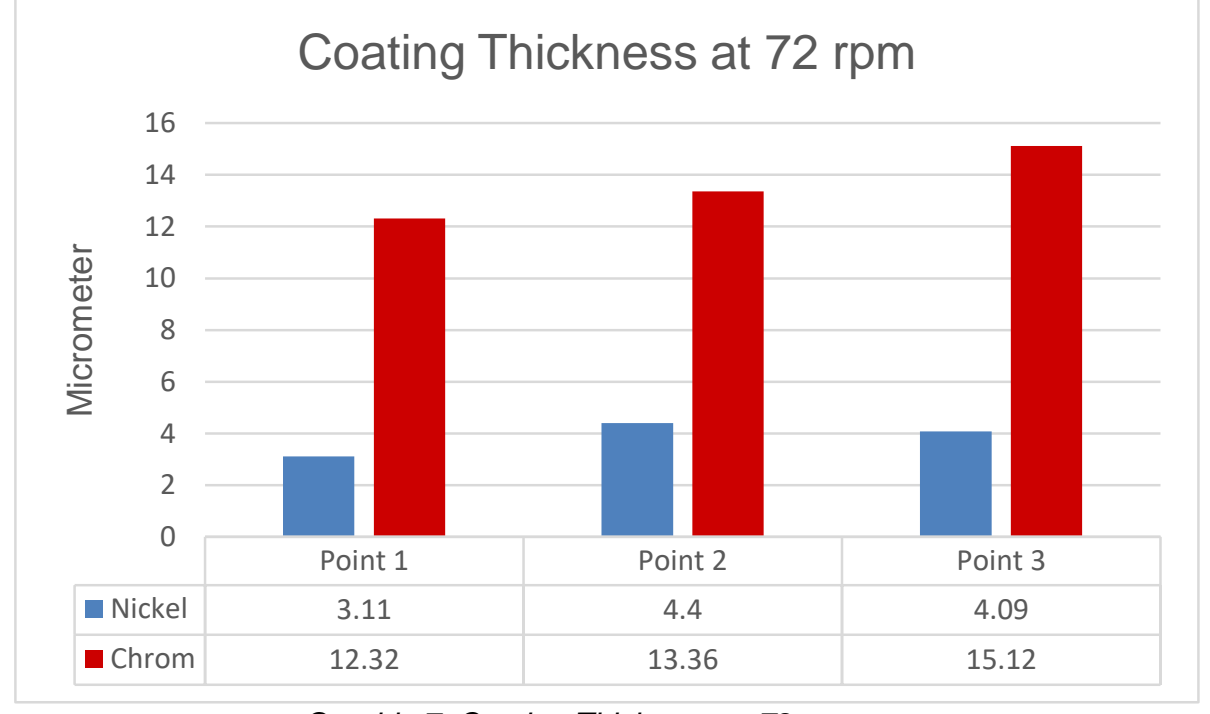

Graphic 7. Coating Thickness at 72 rpm

Based on graphic 7 , the fluctuating results obtained in the nickel layer while the chrome layer has increased from each side. However, these results do not greatly affect the surface of the specimen that has been carried out electroplating process. Judging from the results of the graph above the value of the nickel layer at $72 \mathrm{rpm}$ speed variations are $3,11 \mu \mathrm{m}, 4,4 \mu \mathrm{m}$ and 4,09 $\mu \mathrm{m}$ (nickel) and 12,32 $\mu \mathrm{m}, 13,36 \mu \mathrm{m}$, and 15,12 $\mu \mathrm{m}$. The result of slight fluctuations in the value of the nickel layer is due to the initial surface of the steel before being coated not too flat or surface treatment is less than optimal.

b. Variation Speed of $102 \mathrm{rpm}$

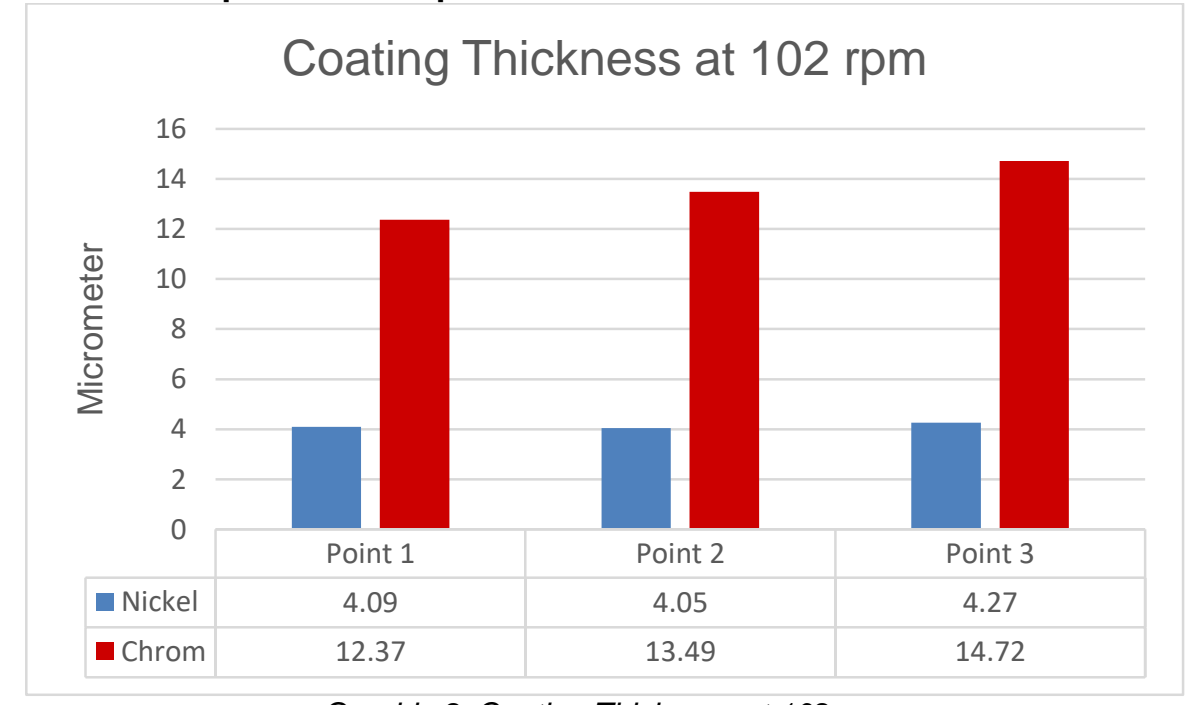

Graphic 8. Coating Thickness at 102 rpm

Based on graphic 8, the fluctuating results obtained in the nickel layer while the chrome layer has increased from each side. However, these results do not greatly affect 
the surface of the specimen that has been carried out electroplating process. Judging from the results of the graph above the value of the nickel layer at $102 \mathrm{rpm}$ speed variations are $4,09 \mu \mathrm{m}, 4,05 \mu \mathrm{m}$ and 4,27 $\mu \mathrm{m}$ (nickel) and 12,37 $\mu \mathrm{m}, 13,49 \mu \mathrm{m}$, and 14,72 $\mu \mathrm{m}$. The result of slight fluctuations in the value of the nickel layer is due to the initial surface of the steel before being coated not too flat or surface treatment is less than optimal.

\section{c. Variation Speed of $132 \mathrm{rpm}$}

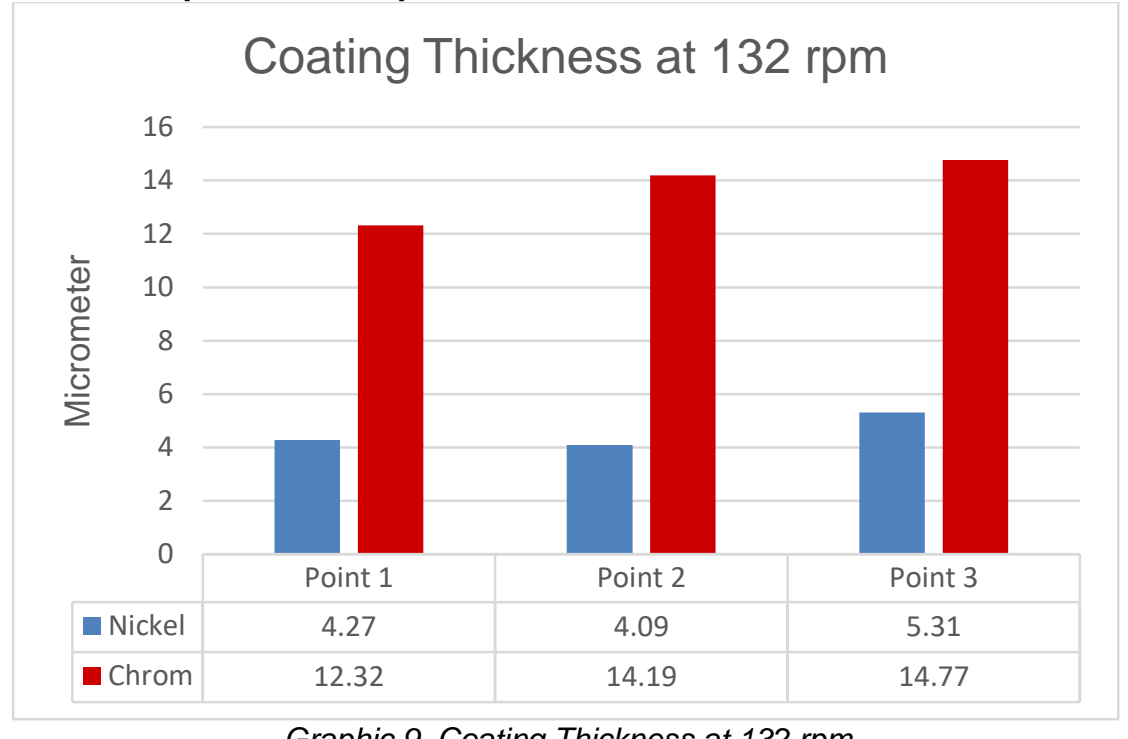

Graphic 9. Coating Thickness at $132 \mathrm{rpm}$

Based on graphic 9, above, the fluctuating results obtained in the nickel layer while the chrome layer has increased from each side. However, these results do not greatly affect the surface of the specimen that has been carried out electroplating process. Judging from the results of the graph above the value of the nickel layer at $132 \mathrm{rpm}$ speed variations are $4,27 \mu \mathrm{m}, 4,09 \mu \mathrm{m}$ and 5,31 $\mu \mathrm{m}$ (nickel) and 12,32 $\mu \mathrm{m}, 14,19 \mu \mathrm{m}$, and 14,77 $\mu \mathrm{m}$. The result of slight fluctuations in the value of the nickel layer is due to the initial surface of the steel before being coated not too flat or surface treatment is less than optimal.

\section{d. Variation Speed of $162 \mathrm{rpm}$}

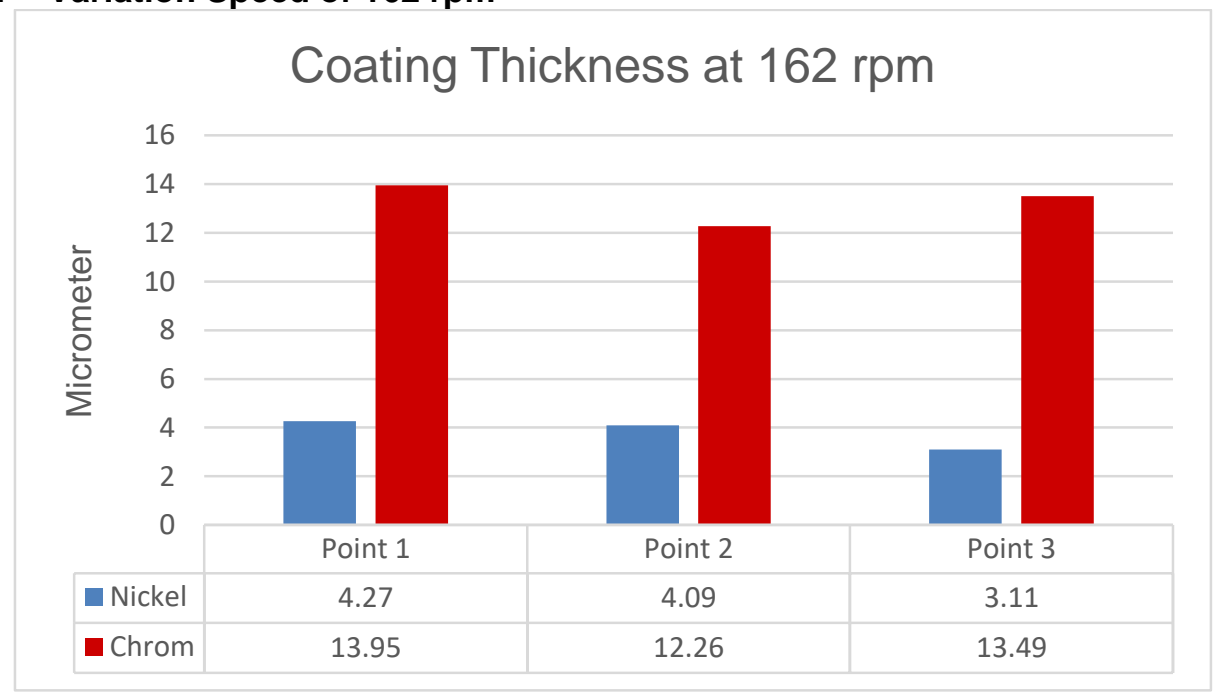

Graphic 10. Coating Thickness at 162 rpm

Based on the graphic 10, the fluctuating results obtained in the chrome layer while the nickel layer has decreased from each side. However, these results do not greatly affect the 
surface of the specimen that has been carried out electroplating process. Judging from the results of the graph above the value of the nickel layer at a speed variation of $162 \mathrm{rpm}$ is $4,27 \mu \mathrm{m}, 4,09 \mu \mathrm{m}$ and 3,11 $\mu \mathrm{m}$ (nickel) and 13,95 $\mu \mathrm{m}, 12,26 \mu \mathrm{m}$, and 13,49 $\mu \mathrm{m}$. The result of slight fluctuations in the value of the chrome layer is due to the initial surface of the steel before being coated not too flat or surface treatment is less than optimal.

\section{e. Graph of Average Coating Thickness For All Speed Variations}

Table 1. Table Thick Nickel Plating

\begin{tabular}{cccccc}
\hline No & $\begin{array}{c}\text { Variation of } \\
\text { Nickel } \\
\text { Electroplating } \\
\text { Rotation } \\
\text { Speed }\end{array}$ & $\begin{array}{c}\text { Point } \\
\text { Thickness } \\
\mathbf{1}(\boldsymbol{\mu m})\end{array}$ & $\begin{array}{c}\text { Point } \\
\text { Thickness } \\
\mathbf{2}(\boldsymbol{\mu m})\end{array}$ & $\begin{array}{c}\text { Point } \\
\text { Thickness } \\
\mathbf{3}(\boldsymbol{\mu m})\end{array}$ & $\begin{array}{c}\text { Thick } \\
\text { Average } \\
(\boldsymbol{\mu m})\end{array}$ \\
\hline 1. & $72 \mathrm{rpm}$ & 3,11 & 4,4 & 4,09 & 3,86 \\
\hline 2. & $102 \mathrm{rpm}$ & 4,09 & 4,05 & 4,27 & 4,13 \\
3. & $132 \mathrm{rpm}$ & 4,27 & 4,09 & 5,31 & 4,55 \\
4. & $162 \mathrm{rpm}$ & 4,27 & 4,09 & 3,11 & 3,82 \\
\hline
\end{tabular}

Table 2. Table Thick Chrome Plating

\begin{tabular}{cccccc}
\hline No & $\begin{array}{c}\text { Variation of } \\
\text { Chrome } \\
\text { Electroplating } \\
\text { Rotation } \\
\text { Speed }\end{array}$ & $\begin{array}{c}\text { Point } \\
\text { Thickness } \\
\mathbf{1}(\boldsymbol{\mu m})\end{array}$ & $\begin{array}{c}\text { Point } \\
\text { Thickness } \\
\mathbf{2}(\boldsymbol{\mu m})\end{array}$ & $\begin{array}{c}\text { Point } \\
\text { Thickness } \\
\mathbf{3}(\boldsymbol{\mu m})\end{array}$ & $\begin{array}{c}\text { Thick } \\
\text { Average } \\
(\boldsymbol{\mu m})\end{array}$ \\
\hline 1. & $72 \mathrm{rpm}$ & 12,32 & 13,36 & 15,12 & 13,6 \\
2. & $102 \mathrm{rpm}$ & 12,37 & 13,49 & 14,72 & 13,52 \\
3. & $132 \mathrm{rpm}$ & 12,32 & 14,19 & 14,77 & 13,76 \\
4. & $162 \mathrm{rpm}$ & 13,95 & 12,26 & 13,49 & 13,23 \\
\hline
\end{tabular}

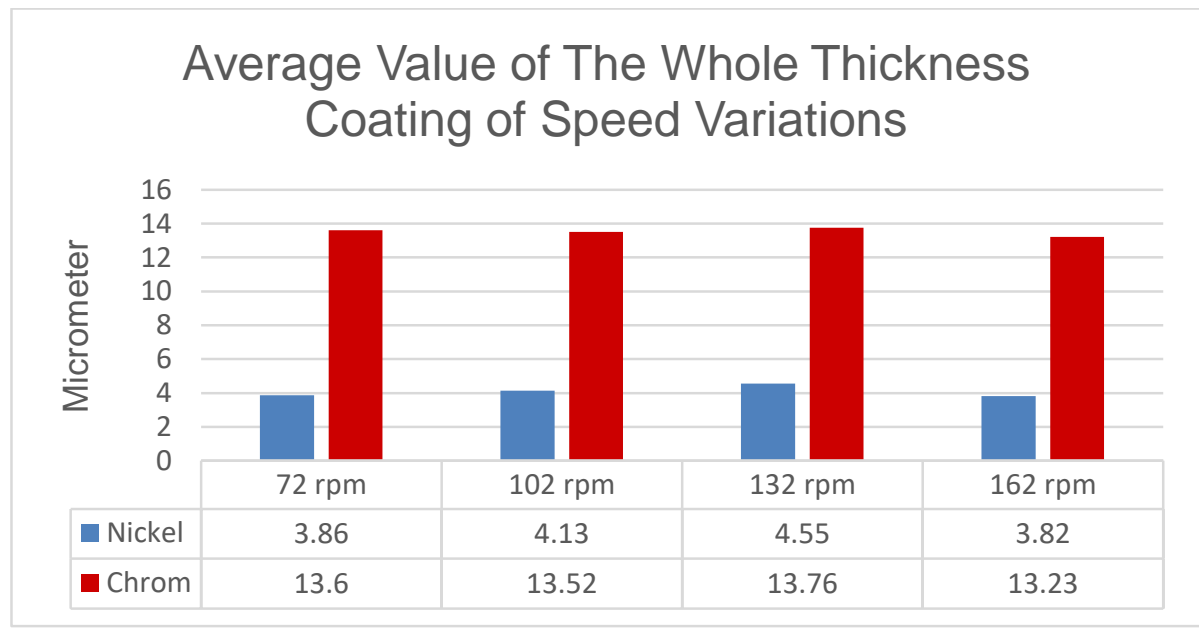

Graphic 11. Average Value of the Whole Thickness Coating of Speed Variations

Based on the graphic 11, the average value of the thickness of the entire variation of the velocity results obtained is quite fluctuating or ups and downs of a thickness value in various variations.

While at $72 \mathrm{rpm}$ and $102 \mathrm{rpm}$ speed variations, the thickness value is added, this indicates that the plating results are attached to the steel specimen before electroplating and rotation per minute are obtained which is the quite optimal and efficient speed for 
electroplating with a magnetic stirrer. Meanwhile, variations of $132 \mathrm{rpm}$ and $162 \mathrm{rpm}$ occur quite fluctuating values, as evidenced by the thickness value of $132 \mathrm{rpm}$ is $4.55 \mu \mathrm{m}$ (nickel), $13.76 \mu \mathrm{m}$ (chrome) and at a speed of $162 \mathrm{rpm}$, the thickness value is $3.82 \mu \mathrm{m}$ (nickel), $13.23 \mu \mathrm{m}$ (chrome).

In theory, the electroplating process works by moving the nickel-chrome ions that move to the specimen (cathode) coating [8]. This is also based on the results of throwing power on the ions contained in the electrolyte must be controlled with a rotation that should not be too fast [9]. Proven in the test results above the thickness value at $72 \mathrm{rpm}$ and 102 rpm rotation variations experienced a fairly good graph change, an increase at $72 \mathrm{rpm}$ rotation and a decrease at $102 \mathrm{rpm}$ rotation, this is following the basic theory of electroplating.

While variations in the rotation of $132 \mathrm{rpm}$ and $162 \mathrm{rpm}$ occur a fairly drastic change in value. It is caused by spinning too fast so that the anode ions moving towards the cathode become uncontrolled and the adhesion process is disrupted. It is possible that the surface of the specimen which should be coated by anode ions is not coated and the part that has been coated, is re-coated without seeing the uncoated part due to too fast a speed. This result is following the previous research In Kwong Hong, et al who mentioned that the stirring speed affects the thickness of the layer [10].

\section{Conclusion}

From the results of research, testing, and discussion of the influence of stirrer RPM variations on the hardness and microstructure results of A36 steel in the decorative nickelchrome electroplating process that has been done, then some conclusions can be drawn as follows, the faster the rpm the more violence is obtained. The highest hardness value is $77.5 \mathrm{VHN}$ at a rotational speed of $132 \mathrm{rpm}$ and the more the rpm speed increases the thickness of the layer increases. The highest thickness is $4.55 \mu \mathrm{m}$ (Nickel) and $13.76 \mu \mathrm{m}$ (Chrome) at a rotational speed of $132 \mathrm{rpm}$.

\section{REFERENCES}

1. M. Azhar Ahmad, "Analisa Pengaruh Besar Tegangan Listrik Terhadap Ketebalan Pelapisan Chrom Pada Pelat Baja Dengan Proses Elektroplating," pp. 1-84, 2011.

2. A. J. Wiley, Modern Electroplating. 2010.

3. R. Niko, "Pengaruh Waktu dan Temperatur Larutan Pelapisan dengan Metode Elektroplating Nikel pada Baja Dengan Bantuan Magnetic Stirrer terhadap Ketebalan dan Kekasaran Permukaan Lapisan.,", pp. 46-47, 2018.

4. T. Kaneko, Electroplating. Yogyakarta: Andi Offset, 1995.

5. R. D. R. N. Mabruri, "Pengaruh Kekasaran Permukaan dan Kecepatan Pengadukan terhadap Karakteristik Lapisan Nirelektrik Ni-P pada Baja Tahan Karat Martensitik." 2018.

6. Dieter, "Mechanical metallurgy - Dieter_George Ellwood.pdf." 1987.

7. S. A. Sajjadi, H. R. Ezatpour, and H. Beygi, "Microstructure and mechanical properties of Al-Al2O3 micro and nanocomposites fabricated by stir casting," Mater. Sci. Eng. A vol. 528, no. 29-30, pp. 8765-8771, 2011, DOI: 10.1016/j.msea.2011.08.052.

8. A. F. Alphanoda, "Pengaruh Jarak Anoda-Katoda dan Durasi Pelapisan Terhadap Laju Korosi pada Hasil Electroplating Hard Chrome," J. Teknol. Rekayasa, vol. 1, no. 1, p. 1, 2017, doi: 10.31544/jtera.v1.i1.2016.1-6.

9. F. Amrulloh and A. E. Palupi, "Febrian Amrulloh Aisyah Endah Palupi Abstrak," Jtm, vol. 02, no. 3, pp. 122-128, 2014.

10. I. K. Hong, H. Kim, and S. B. Lee, "Optimization of barrel plating process for electroless Ni-P plating," J. Ind. Eng. Chem., vol. 20, no. 5, pp. 3767-3774, 2014, DOI: 10.1016/j.jiec.2013.12.077. 